\title{
The Contributions of Reading Strategies and Reading Frequencies toward Students' Reading Comprehension Skill in Higher Education
}

\author{
Amril Amir, Hasanuddin WS, Atmazaki
}

\begin{abstract}
This study was conducted because of the low level of students' reading skill. The reading strategies and the reading frequencies were assumed as the factors affecting students, reading skill. The aim of this study was to describe and to analyze the contribution of reading strategies and reading frequencies toward students' reading comprehension skill. This study used the quantitative method with the descriptive correlational design. The population was 3000 students who attended Bahasa Indonesia subject in Universitas Negeri Padang, and 353 students were taken as samples by using proportional stratified random sampling. The instruments of this study were reading strategies scale, reading frequencies scale and a reading comprehension test which has been valid and reliable. Based on research findings and discussion, the following can be concluded: (1) reading strategies contributed significance and positively to the students' comprehension reading skill which is $19.6 \%\left(R=0.443 R^{2}=0.196\right.$ and $p=0.000$ ), i.e. reading strategies contributed directly toward the skills of reading comprehension. Therefore, the higher the reading strategies, the better the reading comprehension skills of the students; (2) reading strategies contributed significance toward the students' reading comprehension skills of $33.1 \%(R=$ $0.575 R^{2}=0.331$ and $\left.p=0.000\right)$, i.e. reading frequencies contributed directly to reading comprehension skills. Therefore, the better the reading frequencies, the better the reading comprehension skills of the students; (3) reading strategies and the reading frequencies together contributed significance toward the students' reading comprehension skills of $33.2 \%(R=0.575$, $R 2=0.332$ and $p=0.000)$, i.e. reading strategies and reading frequencies together contributed directly to the comprehension reading skill. Therefore, the higher the reading strategies and reading frequencies will be the better the reading comprehension skill of the students.
\end{abstract}

Index Terms: Reading Strategies, Reading Frequencies, Reading Comprehension Skill.

\section{INTRODUCTION}

Reading comprehension skill is really important for students to obtain information from the books, the magazines, and scientific articles which will be useful not only for their future careers (Ahmadi, Ismail, Kamarul, and Abdullah, 2013 Papatga and Ersoy, 2016) but also for their further studies. Reading comprehension is one of the main necessities of students. For example, In the first year of study, reading comprehension is stressed on the explanation of vocabulary in

Revised Manuscript Received on September 22, 2019

Amril Amir, Department of Languange, Faculty of Languange and Art, Universitas Negeri Padang. amril.amir23@yahoo.co.id

Hasanuddin WS, Department of Languange, Faculty of Languange and Art, Universitas Negeri Padang.

Atmazaki, Department of Languange, Faculty of Languange and Art, Universitas Negeri Padang order to help students understand the whole reading passage and will be followed by answering the related questions in spoken or written forms.

The reality is beyond the expectation since most Indonesian students are unfamiliar with the reading strategy or they do not have much reading skill. The data from Central Bureau of Statistic (CBS) in 2012 showed that most Indonesians do not prefer to read as informative sources. They tend to prefer television and the radio as the source of information. The tendency to get information from reading has decreased to $6.05 \%$ as compared to get information through watching television which gained $6.74 \%$. In 2012 , only $17.66 \%$ of Indonesians read while $91.68 \%$ of them watched television and $18.57 \%$ of them listened to the radio (CBS, 2012). Furthermore, the finding of Program of International Student Assessment (PISA) team of Ministry of Education in 2011 showed the habit of 15-year-old children in Indonesia (Junior High and Senior High School levels) was very apprehensive. For literal of read, in 2000 Indonesia was in $39^{\text {th }}$ of 41 countries, in 2003 it was in $39^{\text {th }}$ of 40 countries, in 2006 it was in $48^{\text {th }}$ of 56 countries and in 2009 it was in $57^{\text {th }}$ of 65 countries (PISA, 2015).

If the students low interest and reading ability, then in global competition will always be left behind with fellow developing countries, moreover with other developed countries. Students will not be able to overcome social problem, political, economic, cultural and other issues as long as the sub-man is not competitive, due to lack of mastery of science and technology, weakness of will and ability to read (Musa, 2016). Decreased interest in reading as well affect the competitiveness of Indonesian workers who occupied the 46th place in the world, under Singapore (2), Malaysia (27), Philippines (32) and Thailand (34). However, the quality of Indonesian human resources based on the Human Development Index by the United Nations in 2000, was ranked 109th, the lowest among a number of ASEAN countries, such as Vietnam (108), Japan (9), Singapore (24), Brunei (32), Malaysia (61), Thailand (76) and the Philippines (77)

\section{LITERATURE REVIEW}

Reading is an important activity to enrich knowledge as anyone will be able to understand what he reads when he has the ability to comprehend it (Seraye, 2016). The ability to read fluently is a characteristic of successful language learner (Huang, 2014). The reading ability also shows professionalism and integrity of someone (Massonie et al., 
2018). Even for those who have learning disability, reading ability is still needed (Solari et al., 2017; Van et al., 2017). College students should have a high level of reading comprehension in order to get the information quickly and accurately (Abdellah, 2009; Botsas, 2017). In reading a text, the readers need to understand the information correctly. In this study, reading comprehension means reading by understanding the reading content including the correct associations between meaning and symbol, the context analysis of existing meaning, the correct choice of meaning, the organization of ideas and the storing of arguments for reading activity.

Reading comprehension can be divided into four levels: (1) literal, (2) inferential, (3) evaluation. and (4) appreciation (Yussof et al., 2013; Ulum, 2016). Literal understanding requires ideas, information, and experiences which are clearly stated in the reading passage. Inferential understanding is needed when the readers use the synthesis of literal content of his selection, personal experience, intuition, and imagination as the basic line of the hypotheses. This understanding comes from the questions which require imagination and thought. Evaluation is shown when the reader review a passage and appreciation, obtained when students can appreciate the reading that has been read. Some factors affecting the problem of students' reading comprehension are the mastery of vocabularies, sentence structures, paragraph structures, and passage, or non-linguistic factors like intelligence, gender, reading interest, reading strategy, and reading frequency (Koda, 2005; Kendou, Mcmaster, \& Christ, 2016; Savage, 2017).

The efficient readers understand the goal of reading and are able to form the reading style and the consequent. They have reasons to read and how to get to their goal of reading. Reading comprehension skill is important for students. The lack of reading comprehension skill means flawed readers. The main goal of reading is to gain information from the sources. In order to get it, the readers need to use many reading strategies. Reading strategies are ways to help the readers manage the information they read (Ahmadi et al., 2013). Reading strategies show how somebody gets easier to study and develop the work, especially students who try hard to understand the written context. Some strategies that can be used are skimming, scanning, skipping and flash technique (Ronkova \& Moldova, 2016) as well as work recognizing, one minute reading, survey, question, read, recite and review (SQ3R), survey, question, read, recite, relate and review (SQ4R).

Skimming is reading quickly and accurately to gain main information in newspaper, tabloid, magazines, books, and internet articles (Castillo \& Bonilla, 2014; Rayner et al., 2016; Salmeron et al, 2018). This strategy is used to obtain the facts quickly in every paragraph. It is given to students in order to train the students to read up on an average reading rate to get the main idea of the passage. Scanning is used to get certain information by reading the supporting statements to answer the question. Scanning is used to find specific information such as timetable of schedule, the item of the directory or main point (Castillo \& Bonilla, 2014). To train this technique, a lecturer can give reading passage to the

students and ask questions which are easy to answer based on the text given. It can be repeated by using different kinds of passages. Skipping technique means ignoring irrelevant information which is unnecessary or has been understood.

In a recents study, Koch and Spo (2017) on "Students Improve in Reading Comprehension by Learning How to Teach Reading Strategies. An Evidence-based Approach for Teacher Education ". The results show that certain programs / strategies in reading can improve reading comprehension. Research Malekan and Mohammadi (2017) on "The Relationship between Iranian ESP Learners' Translation Ability and Resilience in Reading Comprehension". The results of the first data analysis revealed that there was a statistically significant relationship between the translation ability of ESP learners and their resilience in reading comprehension. Secondly, there is a significant positive correlation between the translation ability of ESP learners and their reading comprehension.

\section{METHODS}

Quantitative research based on descriptive correlational design was used in this study, i.e. to assess the relationship between reading strategies $\left(\mathrm{X}_{1}\right)$, reading frequencies $\left(\mathrm{X}_{2}\right)$ and students' reading comprehension skill (Y). Techniques of data collection were Questionaire of reading strategies, Questionaire reading frequencies and reading comprehension test that has been filled with validity and reliability. The population of this study was 3000 student and 353 of them were taken as the sample by using proportional stratified random sampling technique. The data were attained in Universitas Negeri Padang through the following procedures: (a) preparing questionnaires for reading strategies and reading frequencies and a reading comprehension test; (b) providing the explanation about the questionnaire and how to fill them; (c) distributing the instruments and inviting students to fill them; and (d) collecting the data. Data were analyzed using descriptive statistic, simple regression and multiple regressions analyses.

\section{RESUlts}

Before conducting the data analysis process, it needs to conduct the normality test where the results are as follows:

TABLE 1. TEST RESULTS NORMALITY

\begin{tabular}{|c|c|c|c|c|}
\hline & \multicolumn{4}{|c|}{$\begin{array}{l}\text { Kolmogorov-Smirn } \text { Shapiro-Wilk } \\
\text { ov }^{\text {a }}\end{array}$} \\
\hline & $\begin{array}{l}\text { Statis } \\
\text { tic }\end{array}$ & Sig. & $\begin{array}{l}\text { Statis } \\
\text { tic }\end{array}$ & Sig. \\
\hline $\mathrm{X} 1$ & 0.10833 & 0.199 & 0.966353 & 0.163 \\
\hline$Y$ & 0.116353 & 0.088 & 0.974353 & 0.334 \\
\hline $\mathrm{X} 2$ & 0.083353 & 0.200 & 0.984353 & 0.714 \\
\hline
\end{tabular}

*. This is a lower bound of the true significance.

a. Lilliefors Significance Correction

After normality test conducted, it shows that the data normally distributed. Then, the test simple regression and multiple regressions were carried out as follows: 


\section{A. Contribution of reading strategies toward student's reading comprehension skill}

The result of analysis of the contribution of reading strategies toward students' reading comprehension is shown in Table 2.

TABle 2. The Result of Simple REgRESSION ANALYSIS AND SIGNIFICANCE ANALYSIS OF $\mathrm{X}_{1}$ TO $\mathrm{Y}$

\begin{tabular}{llll}
\multicolumn{4}{c}{ SIGNIFICANCE ANALYSIS OF $\mathrm{X}_{1}$ TO $\mathrm{Y}$} \\
\hline Model & $\mathrm{R}$ & $\mathrm{R}$ Square & Sig. \\
\hline $\mathrm{X}_{1} \rightarrow \mathrm{Y}$ & 0.443 & 0.196 & 0.000 \\
\hline
\end{tabular}

In Table 2, the correlation coefficient (R) is 0.443 and it showed the coefficient of regression between reading strategies to reading comprehension skill. The level of significance was 0.0000 . The coefficient of determination $\left(R^{2}\right)$ is 0.196 which implies that $19.6 \%$ of reading comprehension can be explained by reading strategies, while $80.4 \%$ of the variation can be explained by other variables. The results of data significance also indicated that the reading strategies has a significance contributed toward reading comprehension skill, i.e. the higher the reading strategies, the better will be the reading comprehension skill.

\section{B. Contribution of reading frequencies toward students' reading comprehension skill}

The result of the analysis of the contribution of reading frequencies to reading comprehension skill is shown in Table 3.

TABLE 3. The Result Of Simple REgRESSION ANALYSIS AND SIGNIFICANCE ANALYSIS OF $\mathrm{X}_{2}$ TO $\mathrm{Y}$

\begin{tabular}{llll}
\hline Model & $\mathrm{R}$ & $\mathrm{R}$ Square & Sig. \\
\hline $\mathrm{X}_{2} \rightarrow \mathrm{Y}$ & 0.575 & 0.331 & 0.000 \\
\hline
\end{tabular}

It can be seen from Table that the coefficient of correlation (R) is 0.575 with the level of significance 0.000 . The $R^{2}$ value is 0.331 which implies that $33.1 \%$ variations of reading comprehension skill can be explained by reading frequencies, meanwhile $66.9 \%$ can be explained by other variables. The results of data significance also indicated that the reading frequencies can predict in reading comprehension skill, i.e. the higher of reading frequencies, the higher his/her reading comprehension skill will be.

\section{Multicollinearity Test}

The result of multicollinierity test can be seen in Table 3 .

Table 4. The Result of Multicollinearity Test BetweEn Reading STRATEGIES $\left(\mathrm{X}_{1}\right)$ AND READING FREQUENCIES $\left(\mathrm{X}_{2}\right)$

\begin{tabular}{lll}
\hline $\begin{array}{l}\text { Variables } \\
\text { (Constant) }\end{array}$ & Tolerance & VIF \\
\hline $\mathrm{X}_{1}$ & 0.973 & 1.028 \\
$\mathrm{X}_{2}$ & 0.919 & 1.089 \\
\hline
\end{tabular}

Table 4 shows the Variance Inflation Factor (VIF) values of reading strategies and reading frequencies were 1.089 and and 1.095 respectively. VIF values are less than 10 , there is no multicollinearity problem between the two independent variables.

\section{Contribution of Reading Strategies and Reading frequencies toward Students' Reading Comprehension Skill}

The result of analysis of the contribution of reading strategies and reading frequencies toward students' reading comprehension is presented in Table 5.
TABLE 5. The Result of Multiple REgRESSION ANALYSES OF $X_{1}$ AND $X_{2}$ TOWARD Y

\begin{tabular}{lll}
\hline Model & $\mathrm{R}$ & $\mathrm{R}$ Square \\
\hline $\mathrm{X}_{1}, \mathrm{X}_{2} \rightarrow \mathrm{Y}$ & 0.575 & 0.332 \\
\hline
\end{tabular}

It can be seen from table 5 that R-value was 0.575 and it showed the coefficient of multiple regressions between reading strategies and reading frequencies toward students' reading comprehension skill. $R$ Square $\left(R^{2}\right)$ value was 0.332 which meant $33.2 \%$ of high-low variations of reading comprehension skill can be explained by both reading strategies and reading frequencies, meanwhile, $66.8 \%$ of them can be explained by other variables. The present study demonstrated that reading strategies and reading frequencies can predict reading comprehension skill.

\section{Discussion}

\section{A. Contribution of Reading Strategies toward Students' Reading Comprehension Skill}

The regression analysis result showed there was the significant relationship between reading strategies to students' reading comprehension skill. The good reading strategies will contribute to attaining the information (Sadeghi, Afghari, and Zarei, 2016). Reading strategies help students to manage and evaluate the ideas which are planned, deliberated, directed, and mentally future-oriented in order to complete the cognitive task (Chen, 2014). Moreover, reading strategies can be used to be a goal of cognitive activity used to establish and maintain the reading competence (Cakici, 2016). Besides that, reading strategies are also useful for improving the reading comprehension of the readers (Salataki, 2002). Reading strategies help students to understand the text well particularly conscious and thoughtful activities. The researcher emphasizes the importance of understanding the reading process itself to help understand the content as previous studies pointed out that mastery of reading strategies often help students to understand the text better for students who have attention problems (Marzban, 2013). The research findings of Zafarani and Kabgani (2014) also showed that the use of various strategies in reading gave a meaningful contribution to understanding the text. Mokhtari and Sheorey (2002) who stated that effective reading strategies will accomplish a better understanding of reading. Another finding from Mujiselaar and De Jong (2014) also showed that the predictors of reading strategies are able to improve reading comprehension. Student could use the strategies and frequencies in reading to improve their abilities in the reading comprehension. To do so, they can rely on the strategies enriching reading such as finding relations between the concepts to be mentioned in a text, categorizing the information presented andunderstanding the meaning of required terms and vocabularies, extracting subcategories, focusing on major and minor ideas, and concentrating on the specific grammatical points and structures used in the text ideas (Kamali and Fahim, 2011; Karimi \& Veisi, 2016; Kendeou, Lynch, van den Broek, Espin, White, and Kremer, 2005). Employing strategies in reading comprehensions, students can develop the strategies required for the 
proper text analysis and accordingly they might able good reading comprehensions. (Montafej \& Nemati, 2014).

\section{B. Contribution of Reading Strategies and Frequencies toward Students' Reading Comprehension Skill}

The research finding showed that both reading strategies and reading frequencies have significant contribution toward reading comprehension skill whereby $33.2 \%$ of variation can be explained by these two variables. This is consistent with a study by Zsigmond (2015) which shows the applicability in using reading and writing strategies to improve students reading comprehension. In addition, the use of reading strategies affects the better reading understanding (Kasimi, 2010) which implies that the strategies used in reading will affect the readers' understanding about the text (Ditzel, 2010; Mytcowicz, et al. 2014; Ahmadi et al., 2013). This is also consistent with the reading frequency of students. Every skill should be well trained, because students tend to be trained if they have the time and opportunity to practice. If they are trained to use reading strategies, they will use them and their reading ability will be improved (Mokhtari \& Sheorey, 2002).

\section{CONCLUSION AND RECOMMENDATION}

Based on research findings and discussion, the following can be concluded: (1) reading strategies contributed significance and positively to the students' comprehension reading skill which is $19.6 \%\left(R=0.443 R^{2}=0.196\right.$ and $p=$ $0.000)$, i.e. reading strategies contributed directly toward the skills of reading comprehension. Therefore, the higher the reading strategies, the better the reading comprehension skills of the students; (2) reading strategies contributed significance toward the students' reading comprehension skills of $33.1 \%$ $\left(\mathrm{R}=0.575 \mathrm{R}^{2}=0.331\right.$ and $\left.\mathrm{p}=0.000\right)$, i.e. reading frequencies contributed directly to reading comprehension skills. Therefore, the better the reading frequencies, the better the reading comprehension skills of the students; (3) reading strategies and the reading frequencies together contributed significance toward the students' reading comprehension skills of $33.2 \%(\mathrm{R}=0.575, \mathrm{R} 2=0.332$ and $\mathrm{p}=0.000)$, i.e. reading strategies and reading frequencies together contributed directly to the comprehension reading skill. Therefore, the higher the reading strategies and reading frequencies will be the better the reading comprehension skill of the students.

According to the research findings, discussion and conclusion, there are three suggestions worth consideration: (a) the lecturers and Language Center should keep improving students' reading comprehension skills by providing the students special programs on reading comprehension; (b) language lecturers can make reading as an initial activity in every meeting in the classroom. Lecturers with students must prepare a short reading material in accordance with the context of his age and course materials taken from various sources. This could improve the reading strategies and reading frequency that contribute to the level of reading comprehension skill; and (c) to the Rectors of Higher Education to support the lecturers and Language Center to provide the program to improve students' reading comprehension in Higher Education. (d) Materials developers and syllable designers in the reading comprehension domain also could employ the findings of the present study and those of the similar ones to present tasks in which learners' awareness toward second language reading and strategies or frequencies in reading comprehension are enhanced. Such tasks may help the learners move towards self-correction, autonomy, and meaningful learning as well.

\section{CONFLICT OF INTEREST}

The author declares no conflict of interest.

\section{ACKNOWLEDGMENTS}

We would like to acknowledge the assistance by all students who participated and completed the research questionnaires.

\section{REFERENCES}

[1] Abdellah, A.S.. (2009). Eye vs Text movement; Which technique leads to faster reading comprehension? CDELT Occasional Papers, 48, 1-27.

[2] Ahmadi, M. R., Ismail, H. N., Kamarul, M., \& Abdullah, K. (2013). The Importance of Metacognitive Reading Strategy Awareness in Reading Comprehension, English Language Teaching, 6, 235-244.

[3] Central Bureau of Statistics. (2012). Socio-Cultural Indicators http://www.bps.go.id/webbeta/frontend/index.php/Subjek/view/27\#su bjekViewTab3

[4] Botsas, G. (2017). Differences in Strategy Use in the Reading Comprehension of Narrative and Science Texts Among Students With and Without Learning Disabilities. Contemporary Journal, 15, 139-162.

[5] Cakici, D. (2016). Teachers 'Beliefs about the use of Reading Strategies. Journal Of Language and Linguistic Studies, 12, 183-194.

[6] Castillo, A. I., \& Bonilla, S. J. (2014). Building up Autonomy Through Reading Strategies. Profile, 16, 67-85.

[7] Chen, J., (2014). Reading Strategies Employed by University Business English Majors with Different Levels of Reading Proficiency. English Language Teaching, 7, 25-37.

[8] Ditzel, S. N. (2010). Metacognitive reading strategies can improve self-regulation. Journal of College Reading and Learning, 40, 45-63.

[9] Duke, N. K., \& Pearson, P. D. (2002). Effective Practices for Developing Reading Comprehension. International Reading Association, 205-242.

[10] Huang, H. (2014). Online Versus Paper-based Instruction: Comparing Two Strategy Training Modules for Improving Reading Comprehension. RELC Journal, 45, 165 - 180.

[11] Kamali, Z., \& Fahim, M. (2011). The relationship between critical thinking ability of Iranian

[12] EFL learners and their resilience level facing unfamiliar vocabulary items in reading.

[13] Journal of Language Teaching and Research, 2(1), 104-111

[14] Karimi, L., \& Veisi, F. (2016). The impact of teaching critical thinking skills on reading

[15] comprehension of Iranian intermediate EFL learners. Theory and Practice in Language Studies, 6(9), 1869-1876.

[16] Kasimi, Y. (2010). Cognitive and metacognitive strategies employed by Iranian and Turkish EFL learners (Unpublished doctoral dissertation) (Online) Hacettepe University, Ankara, Turkey.

[17] Kendeou, P., Lynch, J. S., van den Broek, P., Espin, C., White, M., \& Kremer, K. E.

[18] (2005). Developing successful readers: Building early narrative comprehension skills through television viewing and listening. Early Childhood Education Journal, 33, 91-98.Koda, K. (2005). Insights into second language reading: A cross-linguistic approach. Cambridge, England: Cambridge University Press.

[19] Macalister, J. (2010). Speed reading courses and their effect on reading authentic texts: A preliminary investigation. Reading in a Foreign Language, 22, 104-116.

[20] Marzban, A., \& Akbarnejad, A. A. (2013). The Effect of Cooperative Reading Strategies on Improving Reading Comprehension of Iranian University Students. Procedia - Social and Behavioral Sciences, 70, 936-942. 
[21] Meniado, J. C. (2016). Metacognitive Reading Strategies, Motivation, and Reading Comprehension Performance of Saudi EFL Students 9: 117-129. https://doi.org/10.5539/elt.v9n3p117.

[22] Mokhtari, K., \& Sheorey, R. (2002). Measuring ESL students' awareness of reading strategies. Journal of Development Education, $25,2-10$.

[23] Montafej, J., \& Nemati, A. (2014). Investigating translation competence and its sub-

[24] competencies through different viewpoints and proposing PACTE group model as the best one. International Journal of Language Learning and Applied Linguistics World (IJLLALW), 5(1), 16-27.

[25] Papatga, E., \& Ersoy, A. (2016). Improving Reading Comprehension Skills Through the SCRATCH Program. International Electronic Journal of Elementary Education, 9, 124-150.

[26] PISA. (2015). Survey International PISA. http://litbang.kemdikbud.go .id/index.php/survei internasional- PISA,

[27] Rayner, K., Schotter, E. R., Masson, M. E. J., Potter, M. C., \& Treiman, R. (2016). So Much to Read, So Little Time: How Do We Read, and Can Speed Reading Help ?. Psychological Science in the Public Interest, 17, 4-34

[28] Sadeghi, E., Afghari, A., \& Zarei, G. (2016). Shadow-Reading Effect on Reading Comprehension: Actualization of Interactive Reading Comprehension: ( A Vygotskyan View!). English Language Teaching, 9, 130-138.

[29] Savage, R. (2017). Linguistic and reading comprehension in simultaneous dual language instruction: Evidence against unitary constructs. International Journal of Bilingualism, 5, 1-20.

[30] Seraye, A. M. (2016). Short Vowels Versus Word Familiarity in the Reading Comprehension of Arab Readers : A Revisited. International Electronic Journal of Elementary Education, 8, 81-506.

[31] Solari, E. J., Grimm, R., McIntyre, N. S., Lerro, L. S., Zajic, M., \& Mundy, P. C. (2017). The relation between text reading fluency and reading comprehension for students with autism spectrum disorders. Research in Autism Spectrum Disorders, 41, 8-19.

[32] Weiner, Harvey S. (1985). Reading Skill Hand Book. Houghton Mifflin Co. USA.

[33] Ulum, Ö. G. (2016). A Descriptive Content Analysis of the Extent of Bloom's Taxonomy in the Reading Comprehension Questions of the Course Book Q: Skills for Success 4 Reading and Writing. The Qualitative Report, 21, 1674-1683.

[34] Van Wingerden, E., Segers, E., Van Balkom, H., \& Verhoeven, L. (2017). Foundations of reading comprehension in children with intellectual disabilities. Research in Developmental Disabilities, 60 , 211-222.

[35] Wotschack, C., \& Kliegl, R. (2013). Reading strategy modulates parafoveal-on-foveal effects in sentence reading. Quarterly Journal of Experimental Psychology, 66, 548-562.

[36] Yildiz, M., \& Çetinkaya, E. (2017). The Relationship between Good Readers ' Attention, Reading Fluency and Reading Comprehension. Universal Journal of Educational Research, 5, 366-371.

[37] Yussof, Y.M., Jamian, A.R., Hamzah, Z.A.Z., Roslan, A. (2013) Students' Reading Comprehension Performance with Emotional. International Journal of Education and Literacy Studies, 1, 82-88,

[38] Zafarani, P., \& Kabgani, S. (2014). Summarization Strategy Training and Reading Comprehension of Iranian ESP Learners. Procedia Social and Behavioral Sciences, 98, 1959-1965.

[39] Zsigmond, I. (2015). Writing Strategies for Fostering Reading Comprehension. Procedia - Social and Behavioral Sciences, 180, 1698

\section{AUTHORS PROFILE}

Amril Amir, Department of Languange, Faculty of Languange and Art, Universitas Negeri Padang. amril.amir23@yahoo.co.id

Hasanuddin WS, Department of Languange, Faculty of Languange and Art, Universitas Negeri Padang.

Atmazaki, Department of Languange, Faculty of Languange and Art, Universitas Negeri Padang 